\title{
Hypotensive effect and endothelium-dependent vascular action of leaves of Alpinia purpurata (Vieill) K. Schum
}

\author{
Alessandra Tesch da Silva ${ }^{1}$, Ewelyne Miranda de Lima1, Isabela Faco Caliman², Leonardo Luiz \\ Souza Porto ${ }^{1}$, Andrews Marques do Nascimento ${ }^{1}$, Iêda Carneiro Kalil ${ }^{1}$, Dominik Lenz ${ }^{1}$, Nazaré \\ Souza Bissoli², Denise Coutinho Endringer ${ }^{1,4, *}$, Tadeu Uggere de Andrade, ${ }^{1,3, *}$
}

\begin{abstract}
${ }^{1}$ Department of Pharmacy, University of Vila Velha, Vila Velha, ES, Brazil, ${ }^{2}$ Department of Physiological Sciences, Federal University of Espirito Santo, Vitória, ES, Brazil, ${ }^{3}$ Department of Pharmaceutical Sciences, Federal University of Espirito Santo, Vitória, ES, Brazil, ${ }^{4}$ Campus Vila Velha, Federal Institute of Espirito Santo, Vila Velha, ES, Brazil
\end{abstract}

\begin{abstract}
The aims of this study were to evaluate the chemical profile, vascular reactivity, and acute hypotensive effect (AHE) of the ethanolic extract of leaves of Alpinia purpurata (Vieill) K. Schum (EEAP). Its chemical profile was evaluated using HPLC-UV, ICP-OES, and colorimetric quantification of total flavonoids and polyphenols. The vascular reactivity of the extract was determined using the mesenteric bed isolated from WKY. AHE dose-response curves were obtained for both EEAP and inorganic material isolated from AP (IAP) in WKY and SHR animals. Cytotoxic and mutagenic safety levels were determined by the micronucleus test. Rutin-like flavonoids were quantified in the $\operatorname{EEAP}(1.8 \pm 0.03 \%)$, and the total flavonoid and polyphenol ratios were $4.1 \pm 1.8 \%$ and $5.1 \pm 0.3 \%$, respectively. We observed that the vasodilation action of EEAP was partially mediated by nitric oxide $\left({ }^{\circ} \mathrm{NO}\right)$. The IAP showed the presence of calcium $\left(137.76 \pm 4.08 \mu \mathrm{g} \mathrm{mg}^{-1}\right)$. The EEAP and IAP showed an AHE in WKY and SHR animals. EEAP did not have cytotoxic effects or cause chromosomic alterations. The AHE shown by EEAP could result from its endothelium-dependent vascular action. Rutin-like flavonoids, among other polyphenols, could contribute to these biological activities, and the calcium present in EEAP could act in a synergistic way.
\end{abstract}

Uniterms: Alpinia. Alpinia purpurata/phytochemistry. Alpinia purpurata/ethanolic extract/vascular reactivity. Alpinia purpurata/ethanolic extract/acute hypotensive effect. Flavonoids/quantification. Polyphenols/quantification.

Os objetivos deste estudo foram avaliar o perfil químico de folhas de Alpinia purpurata K. Schum (AP), assim como a reatividade vascular e o efeito hipotensor agudo (EHA) do extrato etanólico de folhas de AP (EEAP). Avliou-se o perfil químico utilizando-se HPLC-UV, ICP-OES e quantificação colorimétrica de flavonoides e polifenóis totais. A reatividade vascular foi determinada utilizando leito mesentérico isolado de ratos WKY. Curvas dose-resposta do EEAP e do material inorgânico da AP (IAP) foram realizadas em animais SHR e WKY. Determinaram-se a segurança citotóxica e mutagênica pelo teste de micronúcleos. Flavonoides tipo rutina foram quantificados no $\operatorname{EEAP}(1,8 \pm 0,03 \%)$ e flavonoide total e polifenóis foram de $4,1 \pm 1,8 \%$ e $5,1 \pm 0,3 \%$, respectivamente. Observou-se ação vasodilatadora do EEAP, mediada parcialmente pelo óxido nítrico $\left({ }^{\circ} \mathrm{NO}\right)$. O IAP revelou a presença de cálcio $(137,76 \pm 4.08$ $\mu \mathrm{g} . \mathrm{mg}^{-1}$ de Ca). O EEAP e IAP apresentaram EHA em animais WKY e SHR. Não se observaram efeitos citotóxicos e alterações cromossômicas provocadas pelo EEAP. O EEAP mostrou um EHA que poderia resultar de ação vascular dependente do endotélio. Rutina, entre outros polifenóis e flavonoides, poderia estar contribuindo para essas atividades biológicas e o cálcio presente no EEAP, poderia agir de maneira sinérgica.

Unitermos: Alpinia. Alpinia purpurata/fitoquímica. Alpinia purpurata/extrato etanólico/reatividade vascular. Alpinia purpurata/extrato etanólico/efeito hipotensor agudo. Flavonoides/quantificação. Polifenóis totais/quantificação.

\footnotetext{
*Correspondence: T. U. Andrade. D. C. Endringer, Programa de Pós-graduação em Ciências Farmacêuticas, Universidade Vila Velha. Rua Comissário José Dantas de Melo, 21 Boa Vista, 29102-770 - Vila Velha - ES, Brasil. E-mail: tadeu.andrade@uvv.br; denise.endringer@uvv.br
} 


\section{INTRODUCTION}

With the increasing life expectancy of the general population, there is an increased prevalence of many chronic diseases, such as hypertension (Fuchs et al., 2001). Hypertension is characterized by maintenance of sustained high blood pressure levels (above 140/80 $\mathrm{mmHg}$ ) (Chobanian et al., 2003; WHO, 2003), and it contributes significantly to serious complications such as stroke, myocardial infarction, congestive heart failure, and chronic renal failure (WHO, 1999; Chobanian et al., 2003; WHO, 2003; Kaplan, Opie, 2006; Thayer, Lane, 2007).

Endothelial dysfunction plays an important role in hypertension (i.e., elevated blood pressure) and contributes to complications in patient condition (Higashi et al., 2002). The role of the endothelium is of particular importance, since it regulates vascular smooth muscle tone and the release of relaxing factors (Török, 2000) such as nitric oxide ( $\left.{ }^{\circ} \mathrm{NO}\right)$, prostacyclin, and endotheliumderived hyperpolarizing factor (EDHF; Luksha, Agewall, Kublickiene, 2009).

Several studies have demonstrated medicinal plants' effects on blood pressure by various mechanisms, such as increased release of ${ }^{\circ} \mathrm{NO}$ and EDHF (Rocha et al. 2007; Victório et al., 2009a; Khan et al., 2012; Senejoux et al., 2012). The hydroalcoholic and aqueous extracts (De Moura et al., 1998) and essential oils (Victório, Kuster, Lage, 2009b; Barcelos et al., 2010) of the Alpinia zerumbet (Pers.) Burtt et Smith (AZ) have been reported to promote a hypotensive effect. Another species of Alpinia, the Alpinia purpurata (Vieill) K. Schum (AP), shows phytochemical similarity with $\mathrm{AZ}$ in terms of the composition of its essential oil (Victório et al., 2009a) and the presence of flavonoids therein (Victório, Kuster, Lage, 2009c).

Mladenka et al. (2010) revised the benefits of flavonoids in the prevention and treatment of cardiovascular diseases, reporting their capacity to reduce blood pressure in hypertensive rats without any normotensive effect. Victório et al. (2009a) reported that the hydroalcoholic extract of AP leaves is rich in flavonoids and can elicit relaxation of the mesenteric vascular bed. However, the participation of relaxant factors from the endothelium in this action (and their hypotensive effects) have not been evaluated yet.

We hypothesized that AP's vasodilatory action results in the hypotensive effect via an endotheliumdependent mechanism. Therefore, the purposes of the present study were to evaluate the mesenteric vascular bed reactivity with and without pharmacological blockade of relaxant factors from the endothelium and the hypotensive effect of the ethanolic extract of AP leaves, its cytotoxic and mutagenic safety, and its chemical profile using HPLC-RP, ICP-OES, and colorimetric quantification of total flavonoids and polyphenols.

\section{MATERIAL AND METHODS}

\section{Plant material}

Alpinia purpurata (Vieill) K. Schum was collected in August 2010 in Garden City Park in Maruípe, Vitória, Espirito Santo and identified by Prof ${ }^{a}$. M.Sc. Solange Z. Schneider, botanic of the herbarium at the University Vila Velha (UVV), where a voucher specimen is deposited under the number UVVES 2036.

\section{Chemical material}

All referenced chemicals and substances, unless otherwise specified were purchased from Sigma-Aldrich Chemical Co. (St Louis, MO, USA). Ultrapure water was used in all stages (ELGA purifier, $18.2 \Omega$ ).

\section{Extraction and isolation}

The leaves of the plant were dried and ground. The dried material was submitted to ultrasound-assisted extraction with ethanol $\left(0.6 \mathrm{~g} \mathrm{~mL}^{-1}\right)$ at room temperature. The solvent was removed in a rotary evaporator (Fisatom) at $50{ }^{\circ} \mathrm{C}$, yielding a greenish residue $(8.2 \mathrm{~g}$, EEAP). The EEAP was mixed in water and submitted to partition with dichloromethane and buthan-1-ol, yielding three fractions: dichloromethane extract, buthanolic extract, and an aqueous fraction $(0.2 \mathrm{~g}, 4.0 \mathrm{~g}$, and $1.0 \mathrm{~g}$, respectively). Based on the available mass and thin layer chromatography profile, the buthanolic fraction was selected for fractionation. After its dispersion in methanol, the formed precipitate was removed by centrifugation at $8460 \mathrm{~g}$, affording $1.5 \mathrm{~g}$ of a colorless crystalline precipitate. The soluble part of the buthanolic fraction $(2.1 \mathrm{~g})$ was concentrated.

\section{Spectroscopic methods}

Determination of metal content was performed in an inductively coupled plasma optical emission spectrometer (ICP-OES; Varian model 720) with ICP Expert II software for data analysis. The infrared (IR) spectra were obtained on a Perkin Elmer spectrophotometer model Spectrum BX 79589 at room temperature. The spectra were obtained by diluting the sample in a $1 \%$ solution of potassium bromide $(\mathrm{KBr})$. 


\section{Determination of water matter in the inorganic material isolated from the 1-buthanol fraction of A. purpurata (IAP)}

The water matter content of the IAP was determined by the gravimetric method (USP, 2006). Analyses were performed in triplicate, and the results were expressed as the percentage \pm standard deviation (SD) in relation to the respective dry plant.

Determination of metal in the ethanolic extract of A. purpurata (EEAP), plant drug, and IAP

EEAP, IAP, and dry plant samples were digested with Merck ultrapure grade $65 \%$ nitric acid and $37 \%$ hydrochloric acid $\left(\mathrm{HNO}_{3}, \mathrm{HCl}, 8: 3\right)$ at $80{ }^{\circ} \mathrm{C}$ until the solution became transparent. The residues were transferred to $25 \mathrm{~mL}$ flasks and diluted to a final defined volume using a $2 \mathrm{M}$ solution of nitric acid. The samples were analyzed for 10 elements: silver, aluminum, barium, beryllium, bismuth, calcium, cadmium, cesium, zinc, and magnesium (Ag, $\mathrm{Al}, \mathrm{Ba}, \mathrm{Be}, \mathrm{Bi}, \mathrm{Ca}, \mathrm{Cd}, \mathrm{Cs}, \mathrm{Zn}$, and $\mathrm{Mg}$, respectively). The analysis was performed on an ICP OES; all concentrations were reported as dry weights $\left(\mu \mathrm{g} \mathrm{mg}^{-1}\right)$.

\section{EEAP chemical profile by high-performance liquid chromatography (HPLC-RP)}

EEAP samples were solubilized in methanol $(\mathrm{MeOH})$ at a concentration of $10 \mathrm{mg} \mathrm{mL}^{-1}$ by sonication for $15 \mathrm{~min}$, followed by centrifugation at $8400 \mathrm{~g}$ for 10 min. Supernatants $(20 \mu \mathrm{L})$ were injected into HPLC equipment (Waters). To obtain sample chromatograms, isocratic elution with a solvent mixture of $\mathrm{MeOH}: \mathrm{H}_{2} \mathrm{O}$ (95:5) was employed in an XBridge ${ }^{\mathrm{TM}}-18$ column $(5 \mu \mathrm{m}$, $250 \times 4 \mathrm{~mm}$ id). The chromatograms were recorded at two wavelengths (254 and $365 \mathrm{~nm}$ ), a flow rate of 0.8

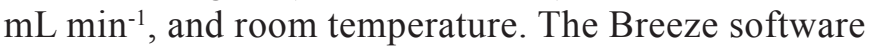
package was used for data processing. A run with coinjection of rutin at $0.048 \mu \mathrm{g} \mathrm{mL}^{-1}$ was performed for confirmation of the type of substance in the sample. A calibration curve of $1.95,3.90,7.80,15.6,31.3,62.5$, 125 , and $250 \mu \mathrm{g} \mathrm{mL}^{-1}$ of the reference rutin substance was constructed. Quantification was performed by external curve with 5 points. The following validation parameters were evaluated: linearity, precision, and limits of detection and quantification. Repeatability was evaluated with seven consecutive assays. The limits of detection and quantification were determined by the levels of signal and noise three and six times, respectively. The equation of the line obtained by linear regression for the standard curve was $\mathrm{y}=54,340,468.67 \mathrm{x}-18,738.54, r^{2}=0.9967$. The linear range was $3.9-125 \mu \mathrm{g} \mathrm{mL}^{-1}$, with a detection limit of $4.83 \mu \mathrm{g} \mathrm{mL}^{-1}$ and a quantification limit of 16.12 $\mu \mathrm{g} \mathrm{mL} \mathrm{m}^{-1}$. The results were expressed as $\mathrm{mg}$ of flavonoids per $100 \mathrm{mg}$ of sample (\%).

\section{Determination of total polyphenols in plant drug and EEAP}

The polyphenol content was determined using the Folin-Ciocalteu method with modifications (Purwantiningsih, Hussin, Chan, 2011; Singleton, Rossi, 1965). Solutions were prepared quantitatively with sample concentrations of $1.5 \mathrm{mg} \mathrm{mL}^{-1}$ (extract) and 25 $\mathrm{mg} \mathrm{mL}^{-1}$ (plant drug). The absorbance was measured at $750 \mathrm{~nm}$ using a spectrophotometer with a methanol blank solution. A calibration curve was prepared with solutions of pyrogallol $\left(10-350 \mu \mathrm{g} \mathrm{mL}^{-1}\right)$; its equation was $\mathrm{y}=$ $0.001244 \mathrm{x}+0.002889, r^{2}=0.9977$. The results were expressed as $\mu \mathrm{g}$ of pyrogallol equivalents (PE) per mg of sample. Analyses were performed in triplicate.

\section{Determination of total flavonoids in plant drug and EEAP}

The colorimetric method employing aluminum chloride $\left(\mathrm{AlCl}_{3}\right.$; Marinova, Ribarova, Atanassova, 2005; El-Beltagi, Salama, El-Hariri, 2007) was used for determination of total flavonoids in these samples. For this assay, $1 \mathrm{~mL}$ of each sample solution $\left(1.5 \mathrm{mg} \mathrm{mL}^{-1}\right.$ and 25 $\mathrm{mg} \mathrm{mL}^{-1}$ for the extract and plant drug, respectively) was used. Absorbance was measured by spectrophotometer (T80+UV/VIS Spectrometer, PG Instruments, Ltd.) at $415 \mathrm{~nm}$. The calibration curve was prepared with solutions of rutin ranging between $31.25-1000 \mu \mathrm{g} \mathrm{mL}^{-1}$ and had the equation $\mathrm{y}=0.0033 \mathrm{x}+0.0121, r^{2}=0.9991$. The results were expressed as $\mu \mathrm{g}$ of rutin equivalents (RE) per milligram of sample. Analyses were performed in triplicate.

\section{Animals}

The animal experiments were performed in accordance with the ethical principles for animal experimentation prepared by the Brazilian College of Animal Experimentation (COBEA, 1991) and were approved by the Ethics Committee, Bioethics and Animal Welfare of UVV (CEUA-UVV; Protocol 120/2010). The experimental groups were composed of spontaneously hypertensive rats (SHR, $n=18$ ) and their normotensive controls (Wistar-Kyoto rats [WKY], $n=18$ ); they were 
housed in individual cages with wood shavings $\left(23^{\circ} \mathrm{C}\right.$ and a 12-h light-dark cycle). All animals had access to food (Probiotério diet, Moinho Primor, SA) and water ad libitum.

\section{Evaluation of the Mesenteric bed of the EEAP}

The superior mesenteric artery and its branches were isolated and perfused with a warmed $\left(37^{\circ} \mathrm{C}\right)$, gassed $(5 \%$ $\mathrm{CO}_{2}$ in $95 \% \mathrm{O}_{2}$ ) physiological salt solution composed of $130 \mathrm{mM} \mathrm{NaCl}, 4.7 \mathrm{mM} \mathrm{KCl}, 1.6 \mathrm{mM} \mathrm{CaCl} \cdot 2 \mathrm{H}_{2} \mathrm{O}$, $1.17 \mathrm{mM} \mathrm{MgSO}_{4} \cdot 6 \mathrm{H}_{2} \mathrm{O}, 14.9 \mathrm{mM} \mathrm{NaHCO}, 1.18 \mathrm{mM}$ $\mathrm{KH}_{2} \mathrm{PO}_{4}, 0.026 \mathrm{mM}$ EDTA, and $11.1 \mathrm{mM}$ glucose, $\mathrm{pH}$ 7.4. Perfusion was maintained at a constant rate of $4 \mathrm{~mL} /$ min with a roller pump, and the perfusion pressure was recorded using a pressure transducer coupled to a MP-100 System Guide (model MP100-CE; Biopac Systems, Santa Barbara, CA, USA). After a stabilization period of $30 \mathrm{~min}$, basal perfusion pressure and dose-response curves were measured with EEAP $(-0.7,-0.4,-0.1,0.2,0.49,0.79$, and $\left.1.09 \log \left[\mathrm{mg} \mathrm{mL}^{-1}\right]\right)$ in mesenteric bed precontracted with norepinephrine $(2.5-10 \mu \mathrm{M}$, in order to achieve stable perfusion pressures of $120-150 \mathrm{mmHg}$ ). One dose of acetylcholine (ACh; $-0.6 \log \left[\mathrm{mg} \mathrm{mL}^{-1}\right]$ ) was used to evaluate the integrity of the endothelium.

\section{Influence of relaxant factor from endothelium on EEAP's vascular action}

Concentration-response curves to EEAP were determined before and after $30 \mathrm{~min}$ preincubation with the NOS inhibitor NG-nitro-L-arginine methyl ester (L-NAME; $100 \mathrm{~mol} \mathrm{~L}^{-1}$ ), L-NAME plus indomethacin $\left(2.8 \times 10^{-6} \mathrm{~mol} \mathrm{~L}^{-1}\right)$, or L-NAME plus indomethacin and clotrimazole $\left(10 \mathrm{~mol} \mathrm{~L}^{-1}\right)$ to evaluate the participation of $\cdot \mathrm{NO}$, prostaglandin, and EDHF, respectively.

\section{Surgical procedures and hemodynamic records}

A polyethylene catheter (PE 50, Clay Adans ${ }^{\circledR}$, USA) was connected to the femoral artery and vein. An incision was made in the inguinal region, under anesthesia with sodium pentobarbital (50 $\mathrm{mg} \mathrm{kg}^{-1}$, intra-peritoneal Hypnol $^{\circledR}$, Crystal, Brazil), with the subsequent isolation of the vascular plexus nerve to allow catheterization. Mean arterial pressure (MAP) and heart rate (HR) were measured in conscious animals $24 \mathrm{~h}$ later using a pressure transducer (Model PT 300, Grass Instrument Div., Warwick, NY, USA) coupled to a Biopac System (MP100, Santa Barbara, CA, USA). The catheter in the femoral vein was used to inject the various doses of EEAP or IAP solutions or saline.

\section{Evaluation of the acute hypotensive effects of the EEAP and IAP}

The hypotensive effect was evaluated via doseeffect curves for the EEAP and IAP. WKY and SHR animals received saline $\left(1 \mathrm{~mL} \mathrm{~kg}^{-1}\right)$ as a negative control to establish a baseline (Soncini et al., 2011), and they then received increasing doses of the EEAP (0.1-100 $\left.\mathrm{mg} \mathrm{kg}{ }^{-1}\right)$ or IAP $\left(0.01-10 \mu \mathrm{g} \mathrm{kg}^{-1}\right)$, both dissolved in saline $(0.9 \% \mathrm{NaCl})$. Subsequent doses were injected only after MAP levels returned to baseline. We evaluated the maximum percentage decrease in MAP after each dose. Acetylcholine (ACh) was used as a positive control (5 $\mu \mathrm{g}$ $\mathrm{kg}^{-1}$, i.v.; Lahlou et al., 2003) before and after EEAP or IAP administration.

\section{In vivo micronucleus test of EEAP}

All micronucleus assays, from bone marrow specimen collection to slide preparation, were run as described by Ribeiro (2003) following the guidelines recommended by the Guideline for the Testing of Chemicals (OECD, 1997). Additionally, this evaluation was performed by a biologist who was blind to the experimental group assignment.

\section{Chromosome alteration and cytotoxicity assay}

WKY rats of both sexes were divided into three experimental groups ( $n=5$ each). Group A, the negative control (NC), received only the vehicle. Group B, the positive control (PC40), received cyclophosphamide (40 mg kg-1 rat) $24 \mathrm{~h}$ before euthanasia. Group C was treated with EEAP $\left(n=5,100 \mathrm{mg} \mathrm{kg}^{-1}\right)$ by oral gavage at $60 \mathrm{~h}, 48 \mathrm{~h}, 36 \mathrm{~h}$, and $24 \mathrm{~h}$ before euthanasia. Chromosome alteration was evaluated by the number of polychromatic erythrocytes with micronucleus (PCEMN) and cytotoxicity by the mitotic index (the polychromatic/ normochromatic erythrocytes ratio [PCE/NCE]).

\section{Statistical analysis}

The values for biological evaluation of the EEAP and IAP were expressed as the mean \pm standard error of mean (SEM), and those of the micronucleus test as the mean $\pm \mathrm{SD}$. The values for baseline MAP and HR, changes in MAP produced by EEAP and IAP, and micronucleus test data were submitted to one-way analyses of variance (ANOVAs) followed by post-hoc Tukey tests for multiple comparisons. To assay vascular reactivity, the data were submitted to two-way ANOVAs followed by Bonferroni 
tests. Differences were considered significant when $p<05$.

The chemical analysis was evaluated using correlation coefficients with the standard curves gathered by linear regression using the least squares method; the data were then analyzed by ANOVAs with a $95 \%$ confidence limit and $n-1$ degrees of freedom.

\section{RESULTS AND DISCUSSION}

The quantification of total flavonoids in the plant drug and extract (Table I) indicates that these metabolites were enriched in the ethanolic extract. The EEAP showed a simple chromatographic profile, and after co-injection of the sample with the flavonoid rutin (Figure 1), the presence of rutin-like flavonoids was suggested. The quantification results indicated $1.8 \% \pm 0.03 \%\left(\mathrm{mg} \mathrm{mg}^{-1}\right)$ of rutin-like content in the extract (obtained by HPLC analysis). The presence of rutin and other flavonoids was observed in other studies conducted with the Alpinia genus, species AP and AZ (Mpalatinos et al., 1998; Victório, Kuster, Lage, 2009c). Rutin was detected in chromatographic profiles of the aqueous extract of AZ (Mpalatinos et al., 1998), hydroethanolic extracts from AZ and AP, and extracts of AP leaves in ethyl acetate $\left(17.8 \mathrm{mg} \mathrm{g}^{-1}\right)$ and butanol (356 $\mathrm{mg} \mathrm{g}^{-1}$ ) (Victório, Kuster, Lage, 2009c). Several factors may influence the content of secondary metabolites, such as seasonality, temperature, water availability, and soil nutrients, which may explain the differences between the levels of flavonoids reported by other authors (GobboNeto, Lopes, 2007) and those found in this study. We also observed a significant enrichment of polyphenols in AP leaves and EEAP (Table I). A similar result was observed by Victório et al. (2009a) using the same method of quantification $\left(30.1 \pm 1.8 \mu \mathrm{g} \mathrm{EP} \mathrm{mg}^{-1}\right)$.

Analysis of the infrared spectrum revealed the inorganic nature of the IAP: bands assigned to $\mathrm{C}-\mathrm{H}$ stretching $\left(2900-2800 \mathrm{~cm}^{-1}\right)$ and C-C stretching $\left(800 \mathrm{~cm}^{-1}\right)$ were absent (Maitz et al., 2002; Boonchom, Danvirutai, 2009; Kanchana, Sundaramoorthi, Jeyanthi, 2009). Phosphates were suggested by the strongest vibrational symmetric mode for the $\mathrm{P}-\mathrm{O}$ bond of the $\left(\mathrm{PO}_{4}{ }^{3-}\right)$ group at $1100 \mathrm{~cm}^{-1}$; the intense band centered at $960 \mathrm{~cm}^{-1}$ was attributed to the asymmetric stretch of $\mathrm{PO}_{4}{ }^{3-}$, and a band centered at $540 \mathrm{~cm}^{-1}$ was attributed to the angular deformation of $\mathrm{PO}_{2}$ in the phosphate group (Boonchom, Danvirutai, 2009). The infrared spectrum of IAP (Figure 2) was similar to the spectrum of an ethanolic solution of calcium phosphate shown by Boonchom and Danvirutai (2009).

The ICP-OES analysis identified calcium (137.76 $\left.\pm 4.08 \mu \mathrm{g} \mathrm{mg}^{-1}\right)$ as the main metal constituent. Other metals (Ba, Be, Bi, Cd, Cs, Ag, Mg and $\mathrm{Zn}$ ) were below the detection limit, except for Al, which presented at a concentration of $0.71 \pm 0.16 \mu \mathrm{g} \mathrm{mg}^{-1}$. As the infrared spectrum showed that $\mathrm{PO}_{4}{ }^{3-}$ was present, it was inferred that IAP is constituted predominantly of calcium phosphate $\left(\mathrm{Ca}_{3}\left[\mathrm{PO}_{4}\right]_{2}\right)$.

Detection of $\mathrm{Ca}^{2+}$ in the plant drug and EEAP was also performed, and as was the case with IAP, that was the metal with the highest concentration. However, given the

TABLE I - Quantification of total polyphenols and flavonoids in Alpinia purpurata leaves and ethanolic extract of AP (EEAP)

\begin{tabular}{lcccc}
\hline Assay & Vegetal material (\%) & EEAP $(\%)$ & LOQ $\left(\mu \mathrm{gL}^{-1}\right)$ & LOD $\left(\mu \mathrm{g} \mathrm{mL}{ }^{-1}\right)$ \\
\hline Total polyphenols $\left(\mathrm{mg} \mathrm{PE} 100 \mathrm{mg}^{-1}\right)$ & $0.7 \pm 0.1$ & $5.1 \pm 0.3$ & 13.7 & 4.1 \\
Flavonoids $\left(\mathrm{mg} \mathrm{RE} 100 \mathrm{mg}^{-1}\right)$ & $1.3 \pm 0.1$ & $4.1 \pm 1.8$ & 5.3 & 1.6 \\
\hline
\end{tabular}

LOQ: limit of quantification; LOD: limit of detection; PE; pyrogallol equivalent; RE: rutin equivalent.
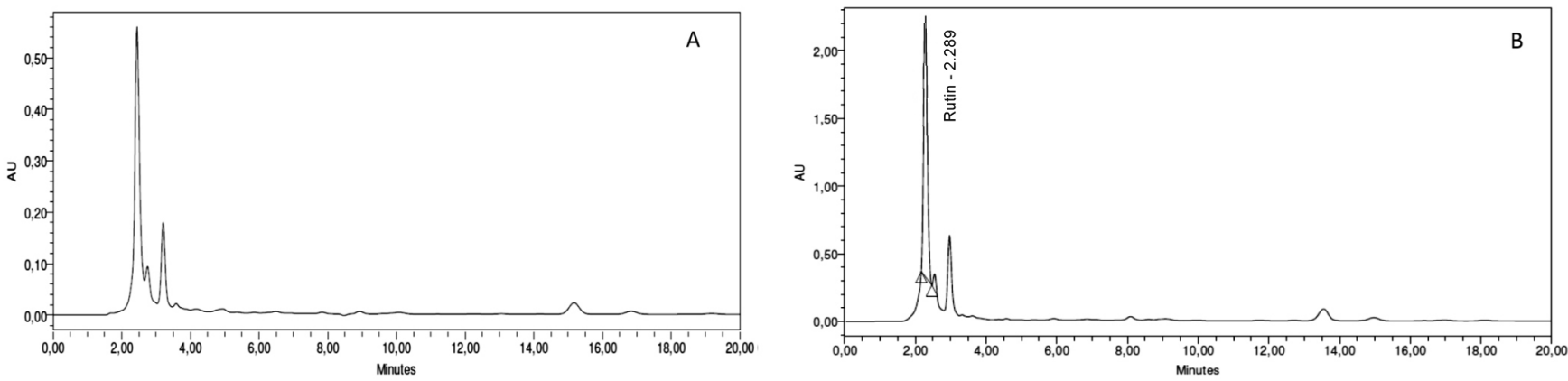

FIGURE 1 - Chromatograms of the ethanolic extract of Alpinia purpurata (EEAP). In A, the concentration of EEAP was 5 mg mL ${ }^{-1}$; in $\mathrm{B}$, the concentration of EEAP was $5 \mathrm{mg} \mathrm{mL}^{-1}+0.048 \mathrm{mg} \mathrm{mL}^{-1}$ rutin. Solvent: $\mathrm{MeOH}: \mathrm{H}_{2} \mathrm{O}(95: 05)$; flow rate: $0.8 \mathrm{~mL} \mathrm{~min}{ }^{-1}, 254 \mathrm{~nm}$. 


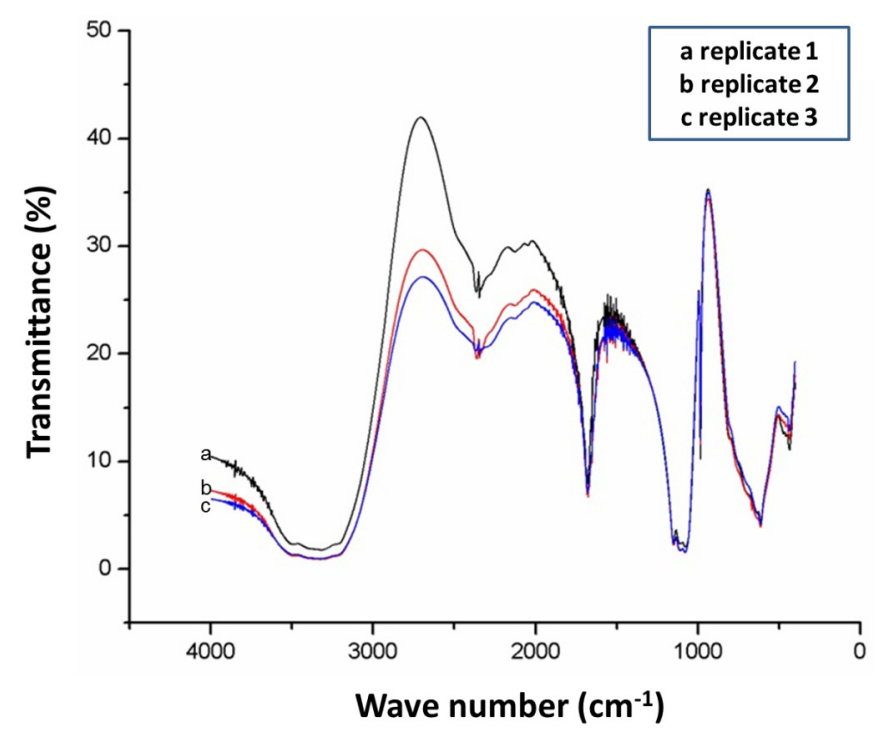

FIGURE 2 - Infrared spectrum of the inorganic material isolated from the butan-1-ol fraction of $A$. purpurata (IAP).

complexity of the matrices of the plant drug and the EEAP, the values were $18.85 \pm 27.14 \mu \mathrm{g} \mathrm{mg}^{-1}$ and $15.93 \pm 26.45$ $\mu \mathrm{g} \mathrm{\textrm {mg } ^ { - 1 }}$, respectively.

The mesenteric bed baseline perfusion pressure was $30.3 \pm 1.2 \mathrm{mmHg}$. Acetylcholine induced mesenteric bed relaxation $(77 \pm 2 \%)$. EEAP produced concentrationdependent mesenteric bed relaxation in the rats (Figure 3 ). After L-NAME was added to the perfusion fluid, the relaxation was greatly reduced at all doses, whereas when both indomethacin and L-NAME were added, this reduction was maintained. However, after clotrimazole was added in conjunction with the latter two blockers, the response to EEAP was abolished.

Endothelium-dependent relaxations are achieved by a combination of endothelium-derived prostacyclin (PGI2), nitric oxide ( $\left.{ }^{\circ} \mathrm{NO}\right)$, and endothelium-derived hyperpolarizing factor (EDHF; Shimokawa et al., 1996; Huang et al., 2001). The results of this study indicate the importance of ${ }^{\circ} \mathrm{NO}$, but not prostanoids, in the dilating response to EEAP. Additionally, the addition of the CYP inhibitor clotrimazole to the nutrition solution with L-NAME and indomethacin abolished EEAP-induced vasodilation. CYP generates epoxyeicosatrienoic acids, metabolites of arachidonic acid that have been suggested to contribute to the EDHF response in animal and human vessels, as they induce the hyperpolarization of endothelial and smooth muscle cells (Busse et al., 2002; Taddei et al., 2006; Yanga, Yima, He, 2007).

As the vascular relaxant action of EEAP was
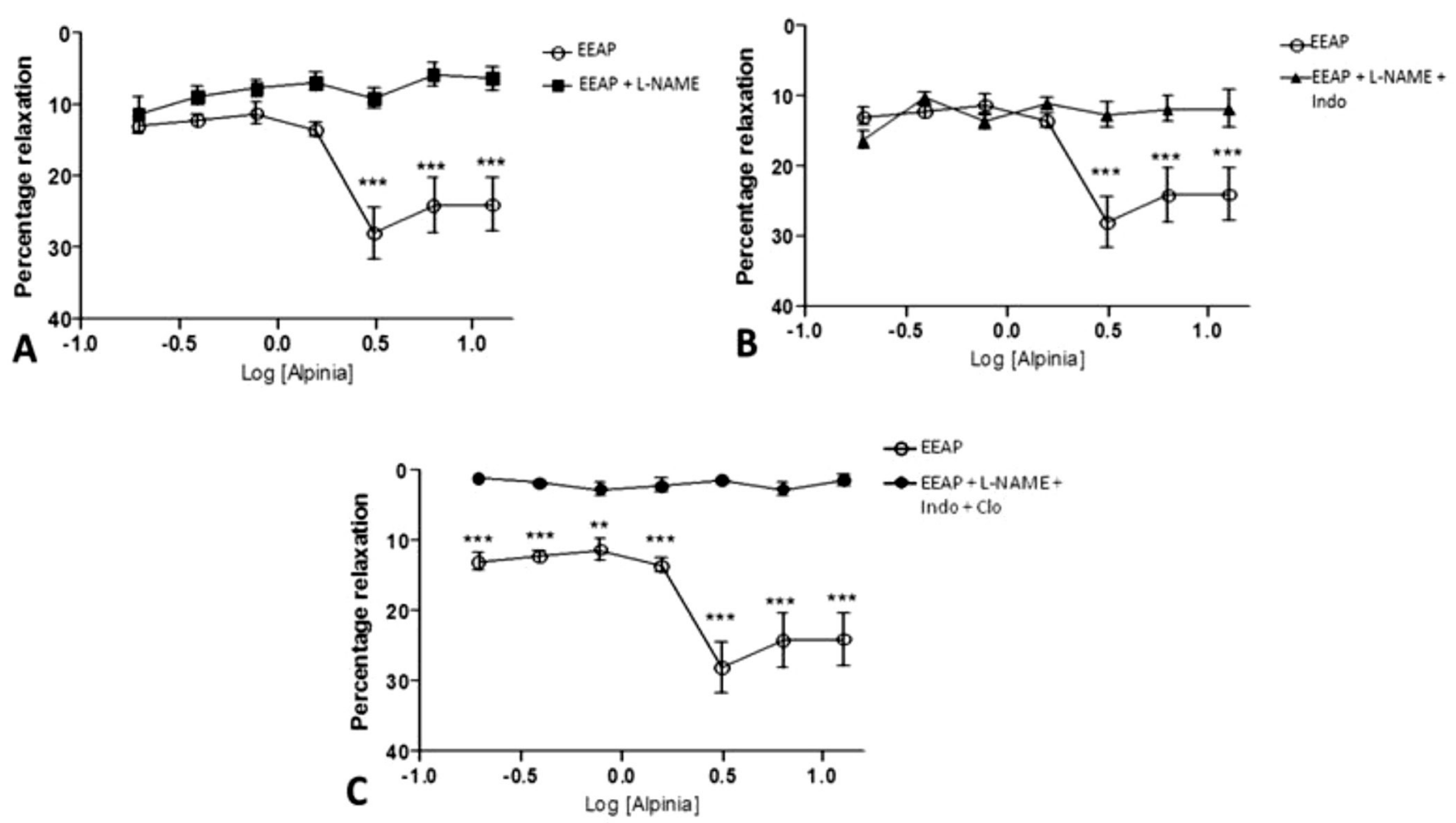

FIGURE 3 - Mesenteric vascular reactivity of EEAP. Panel A: concentration-effect curves of EEAP and EEAP + L-NAME. Panel $\mathrm{B}$ : concentration-effect curves of EEAP and EEAP + L-NAME + indomethacin (Indo). Panel C: concentration-effect curves of $\mathrm{EEAP}$ and EEAP + L-NAME + indo + clotrimazole (Clo). Values are expressed as the mean \pm SEM. ${ }^{* *} p<0.01$ and ${ }^{* * *} p<0.001$ compared with values of EEAP with blocking. 
determined, we investigated whether a hypotensive effect could be elicited by EEAP in vivo. We also tested whether the IAP elicits blood pressure reduction. In in vivo experiments, as expected, the SHR showed high levels of MAP $(155 \pm 4 \mathrm{mmHg}, p<0.01)$ compared with WKY rats $(102 \pm 3 \mathrm{mmHg})$. However, there was no difference in baseline HR (WKY: $365 \pm 10$ bpm; SHR: $378 \pm 11$ bpm) between groups of rats. Figure 4 shows the acute hypotensive effects of the EEAP and IAP, which elicited dose-dependent reductions in MAP in both normotensive (EEAP: $-26 \pm 2 \% ;-30 \pm 3 \% ;-43 \pm 4 \% ;-54 \pm 2 \% ;-63 \pm$ $5 \%$; IAP: $-13 \pm 3 \% ;-16 \pm 3 \% ;-20 \pm 2 \%,-26 \pm 2 \% ;-30 \pm$ $1 \%)$ and hypertensive (EEAP: $-36 \pm 3 \% ;-45 \pm 4 \% ;-58 \pm$ $3 \% ;-70 \pm 2 \%$; $93 \pm 5 \%$; IAP: $-18 \pm 4 \% ;-23 \pm 2 \% ;-32 \pm$ $2 \% ;-36 \pm 1 \%,-46 \pm 1 \%)$ rats. The values differed from the reduction elicited by saline (WKY: $-7 \pm 3 \%$; SHR: -8 $\pm 4 \%$ ) at all doses of EEAP and all but the weakest dose of IAP. Additionally, blood pressure reduction was higher in magnitude in SHR than in normotensive animals $(p<$ $.01)$ at all doses of EEAP, and in all but the two weakest doses of the IAP. Several studies have shown a blood pressure-lowering effect of AZ, a species very similar to AP (Mendonça et al., 1991; Mpalatinos et al., 1998; Lahlou et al., 2002, 2003; De Moura et al., 2005; Barcelos et al., 2010). The study by Mendonça et al. (1991) demonstrated an important blood pressure-lowering effect of the alcoholic extract of AZ in rats. Lahlou et al. (2002) observed that i.v. treatment with the essential oil of AZ induces immediate and significant hypotension in rats. Barcelos et al. (2010) found that chronic treatment with the essential oil of AZ reduced MAP in SHR animals. However, no studies have evaluated the hypotensive effect of AP.

Acetylcholine induced a hypotensive effect both before and after the dose-effect curves of the EEAP and IAP were measured (WKY: $-45 \pm 5 \%$ and $-43 \pm 3 \%$, respectively; SHR: $-53 \pm 3 \%$ and $-51 \pm$ $2 \%$, respectively), indicating vascular integrity. This measurement was important, since vascular relaxation induced by acetylcholine is dependent on the integrity of the endothelial cells (Batlouni, 2001; Victório et al., 2009a).

Victório et al. (2009a) reported the vasodilatory effect of the hydroalcoholic extract of AP in mesenteric bed from Wistar rats pre-contracted with norepinephrine. However, the role of the endothelium in this effect was not evaluated. To our knowledge, the present study's data demonstrate for the first time that EDHF and ${ }^{\circ} \mathrm{NO}$ participate in the acute relaxing response to EEAP in the isolated perfused mesenteric bed, and that the same extract can elicit an in vivo hypotensive effect. The involvement of the ${ }^{\circ} \mathrm{NO}$ pathway in the vasodilatory action (i.e., hypotensive effect) has been reported in AZ. De Moura et al. (2005) demonstrated that vasodilatation induced by the extract of AZ (AZE) is dependent on ${ }^{\circ} \mathrm{NO}$ release; further, they showed that the antihypertensive effect on DOCA-salt hypertensive animals
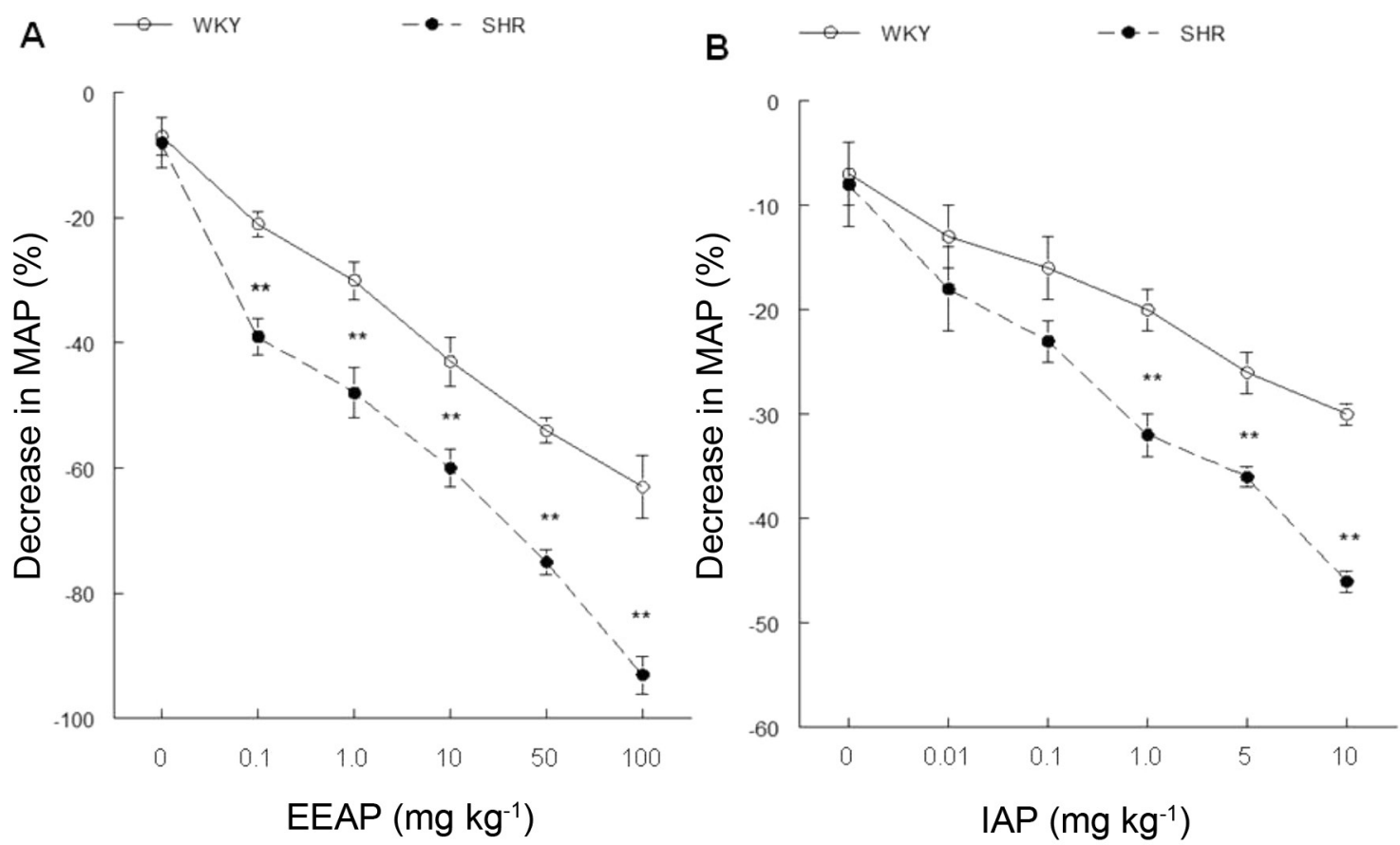

FIGURE 4 - Percentage decrease in MAP after injection of saline $\left(1 \mathrm{~mL} \mathrm{~kg}^{-1}\right)$ and increasing doses of EEAP $\left(0.1-100 \mathrm{mg} \mathrm{kg}{ }^{-1}\right.$; Panel A) and IAP (0.01-10 $\mathrm{mg} \mathrm{kg}^{-1}$; Panel B). Values are expressed as the mean \pm SEM. ${ }^{* *} p<0.01$ compared with WKY animals. 
can be caused by a reduction in vascular resistance induced by a substantial increase in ${ }^{\circ} \mathrm{NO}$ production by endothelial cells. Lahlou et al. (2003) found in their study that the hypotensive response to AZ's essential oil is due to active vascular relaxation.

An interesting finding in our study was the determination of calcium levels in the EEAP. Considering the evidence that dairy products and green vegetables rich in calcium can prevent blood pressure elevation, the acute hypotensive effect of IAP was also evaluated. The results showed that IAP can reduce blood pressure in both normo- and hypertensive animals. Mäkynen et al. (1995) suggested that the reduction of blood pressure associated with increased dietary intake of calcium is induced by increased arterial relaxation. Furspan et al. (1989) and Dominiczak et al. (1991) observed strong evidence that increased extracellular calcium causes reduction in vascular contractility, but stabilization of the vascular membrane. Therefore, the calcium in EEAP could act synergistically with other compounds to determine both the vasodilatory action and the hypotensive effect observed with the administration of EEAP.

We identified the presence of polyphenols and flavonoids in EEAP. Studies have reported the involvement of polyphenols in endothelium-dependent relaxant effects mediated by the liberation of ${ }^{\circ} \mathrm{NO}$ and EDHF (Andriambeloson et al., 1997; De Moura et al., 2002; Ndiaye et al., 2003; De Moura et al., 2004). Senejoux et al. (2012) demonstrated the possibility that polyphenolic compounds found in the extract of Nitraria sibirica Pall fruit are involved in its hypotensive properties and endothelium-dependent relaxation effects; these mainly involve ${ }^{\circ} \mathrm{NO}$ liberation, EDHF, and stimulation of the muscarinic receptors.

Among the polyphenolic compounds, flavonoids have been widely identified and studied (Ramassamy, 2006). A recent study reviewed the role and importance of flavonoids in the prevention of cardiovascular diseases. Reported beneficial effects include inhibition of oxidation of low-density lipoprotein (LDL), antiplatelet activity, anti-inflammatory effects, antioxidant effects, and a hypotensive effect with direct vasodilation (MajewskaWierzbicka, Czeczot, 2012). Mpalantinos et al. (1998) suggested that the anti-hypertensive and diuretic activities of AZ extract are caused by the presence of flavonoids.

Rutin-like flavonoids were identified and quantified in the EEAP. Ferreira et al. (2007) demonstrated that rutin is a major flavonoid found in ethanolic extracts of Hancornia speciosa Gomes, and that it contributes to endothelium-dependent vasodilator activity in rat mesenteric artery. Additionally, Lapa Fda et al. (2011) showed that Polygala paniculata L. extract induces potent vasodilatory action and hypotensive effects via the ${ }^{-} \mathrm{NO}$ pathway and that these effects are related to rutin. Therefore, the presence of polyphenols such as flavonoids (especially rutin) in the EEAP should account for its endothelium-dependent vasodilatory action and its hypotensive effect by releasing ${ }^{\circ} \mathrm{NO}$ and EDHF.

The results of the micronucleus test are shown in Table II. The EEAP, at the dose used $\left(100 \mathrm{mg} \mathrm{kg}^{-1}\right)$, induced no chromosome alterations. There was no significant difference $(p>0.01)$ between MNPCE and the negative control, but significant differences $(p<0.01)$ compared with the positive control (PC40). The result is considered positive for mutagenicity only if the test group shows a statistically significant increase in the frequency of treatment-related MNPCE at any sampling time (Ribeiro, 2003). The EEAP also did not show any cytotoxic activity, since the group treated with EEAP showed a significant difference $(p<0.01)$ in the PCE/NCE ratio relative to the $\mathrm{PC} 40$ group. However, that group's results were not different from those of the NC group. Thus, these data indicated that the EEAP has no cytotoxic activity (Ribeiro, 2003; Leite et al., 2006).

TABLE II - Numbers of normochromatic erythrocytes (NCE), polychromatic erythrocytes (PCE), and micronucleated polychromatic erythrocytes (MNPCE) and the polychromatic erythrocytes/normochromatic erythrocytes (PCE/NCE) ratio in the bone marrow of rats treated with the ethanolic extract of A. purpurata (EEAP) in $0.9 \%$ saline solution

\begin{tabular}{lcccc}
\hline Group & NCE & PCE & MNPCE & PCE/NCE \\
\hline NC & $92.0 \pm 17.6$ & $109.2 \pm 16.9$ & $1.5 \pm 1.3$ & $1.25 \pm 0.40$ \\
PC40 & $146.2 \pm 17.4^{* *}$ & $54.2 \pm 17.1^{* *}$ & $13.4 \pm 3.4^{* *}$ & $0.39 \pm 0.17^{* *}$ \\
EEAP & $91.2 \pm 12.3^{\# \#}$ & $106 \pm 9.8^{\# \#}$ & $1.6 \pm 0.9^{\# \#}$ & $1.18 \pm 0.21^{\# \#}$ \\
\hline
\end{tabular}

NC: negative control; PC40: positive control (cyclophosphamide $\left.40 \mathrm{mg} \mathrm{kg}^{-1}\right)$; EEAP $\left(100 \mathrm{mg} \mathrm{kg}^{-1}\right)$ : group treated with the EEAP in the $0.9 \%$ saline solution. The values are expressed as the mean \pm standard deviation (SD). ${ }^{* *} p<0.01$ compared with negative control and ${ }^{\#} p<0.01$ compared with the positive control. We performed one-way analyses of variance (ANOVAs) followed by post hoc Tukey tests. 
In conclusion, the EEAP presented an acute hypotensive effect, which could result from its endothelium-dependent vascular action. Rutin, among other polyphenols and flavonoids, could contribute to these biological activities, and it is possible that the calcium present in EEAP (determined to be calcium phosphate in IAP isolated from EEAP) could act synergistically. Additionally, EEAP caused no chromosome alterations or cytotoxic effects.

\section{ACKNOWLEDGMENTS}

This study was supported by the Fundação de Amparo à Pesquisa do Espírito Santo and the Fundação para o Desenvolvimento do Ensino Superior Privado.

\section{REFERENCES}

ANDRIAMBELOSON, E.; KLESCHYOV, A.L.; MULLER, B.; BERETZ, A.; STOCLET, J.C.; ANDRIANTSITOHAINA, R. Nitric oxide production and endothelium-dependent vasorelaxation induced by wine polyphenols in rat aorta. Br. J. Pharmacol., v.120, p.1053-1058, 1997.

BARCELOS, F.F.; OLIVEIRA, M.L.; GIOVANINNI, N.P.B.; LINS, T.P.; FILOMENO, C.A.; SCHNEIDER, S.Z.; PINTO, V.D.; ENDRINGER, D.C.; ANDRADE, T.U. Estudo químico e da atividade biológica cardiovascular do óleo essencial de folhas de Alpinia zerumbet (Pers.) B.L. Burtt \& R.M.Sm. em ratos. Rev. Bras. Plantas Med., v.12, p.48-56, 2010.

BATLOUNI, M. Endotélio e hipertensão arterial. Rev. Bras. Hipertens., v.8, p.328-338, 2001.

BOONCHOM, B.; DANVIRUTAI, C. The morphology and thermal behavior of Calcium dihydrogen phosphate monohydrate $\left(\mathrm{Ca}\left(\mathrm{H}_{2} \mathrm{PO}_{4}\right)_{2} \cdot \mathrm{H}_{2} \mathrm{O}\right)$ obtained by a rapid precipitation route at ambient temperature in different media. J. Optoelectron. Biomed. Mater., v.1, p.115-123, 2009.

BUSSE, R.; EDWARDS, G.; FELETOU, M.; FLEMING, I.; VANHOUTTE, P.M.; WESTON, A.H. EDHF: bringing the concepts together. Trends Pharmacol. Sci., v.23, p.374$380,2002$.
CHOBANIAN, A.V.; BAKRIS, G.L.; BLACK, H.R.; CUSHMAN, W.C.; GREEN, L.A.; IZZO, J.L.J.R.; JONES, D.W.; MATERSON, B.J.; OPARIL, S.; WRIGHT, J.T.J.R.; ROCCELLA, E.J. Joint national committee on prevention, detection, evaluation, and treatment of high blood pressure. National heart, lung, and blood institute; national high blood pressure education program coordinating committee. Seventh report of the joint national committee on prevention, detection, evaluation, and treatment of high blood pressure. Hypertension, v.42, p.1206-1252, 2003.

COLÉGIO BRASILEIRO DE EXPERIMENTAÇÃO ANIMAL. COBEA. Princípios éticos na experimentação animal. São Paulo: COBEA, 1991. p.1

DE MOURA, R.S.; AFIATPOUR, P.; DA SILVEIRA, A.V.; DE MELLO, R.G.; NETO, M.D.; ALMAGRO, L.C. Effect of hydroalcoholic extract of colônia (Alpinia zerumbet) on rat arterial blood pressure and on the isolated human saphenous vein. Naunyn. Schmiedebergs Arch. Pharmacol., v.358, p.38-44, 1998.

DE MOURA, R.S.; VIANA, C.F.S.; SOUZA, M.A.; KOVARY, K.; GUEDES, D.C.; OLIVEIRA, E.P. Antihypertensive, vasodilator and antioxidant effects of a vinifera grape skin extract. J. Pharm. Pharmacol., v.54, p.1515-1520, 2002.

DE MOURA, R.S.; MIRANDA, D.Z.; PINTO, A.C.; SICCA, R.F.; SOUZA, M.A.; RUBENICH, L.M.; CARVALHO, L.C.; RANGEL, B.M.; TANO, T.; MADEIRA, S.V.; RESENDE, A.C. Mechanism of the endothelium dependent vasodilation and the antihypertensive effect of Brazilian red wine. J. Cardiovasc. Pharmacol., v.44, p.302-309, 2004.

DE MOURA, R.S.; EMILIANO, A.F.; CARVALHO, L.C.R.; SOUZA, M.A.V.; GUEDES, D.C. Antihypertensive and endothelium-dependent vasoditlation effects of Alpinia zerumbet, a medicinal plant. J. Cardiovasc. Pharmacol., v.46, p.288-294, 2005.

DOMINICZAK, A.F.; LAZAR, D.F.; DAS, A.K.; BOHR, D.F. Lipid bilayer in genetic hypertension. Hypertension, v.18, p.748-757, 1991.

EL-BELTAGI, H.S.; SALAMA, Z.A.; EL-HARIRI, D.M. Evaluation of fatty acids profile and the content of some secondary metabolites in seeds of different flax cultivars (Linumus itatissimum L.). Gen. Appl. Plant Physiol., v.33, p.187-202, 2007. 
FERREIRA, H.C.; SERRA, C.P.; ENDRINGER, D.C.; LEMOS, V.S.; BRAGA, F.C.; CORTES, S.F. Endotelium-dependent vasodilation induced by Hancornia speciosa in rat superior mesenteric artery. Phytomedicine, v.14, p.473-478, 2007.

FUCHS, S.C.; PETTER, J.G.; ACCORDI, M.C.; ZEN, V.L.; PIZZOL, A.D. J.R.; MOREIRA, L.B.; FUCHS, F.D. Establishing the prevalence of hypertension. Influence of sampling criteria. Arq. Bras. Cardiol., v.76, p.445-452, 2001.

FURSPAN, P.B.; RINALDI, G.J.; HOFFMAN, K.; BOHR, D.F. Dietary calcium and cell membrane abnormality in genetic hypertension. Hypertension, v.13, p.727-730, 1989.

GOBBO-NETO, L.; LOPES, N.P. Plantas medicinais: fatores de influência no conteúdo de metabólitos secundários. Quím. Nova, v.30, p.374-381, 2007.

HIGASHI, Y.; SASAKI, S.; NAKAGAWA, K.; MATSUURA, H.; OSHIMA, T.; CHAYAMA, K. Endothelial function and oxidative stress in renovascular hypertension. N. Engl. J. Med., v.346, p.1954-1962, 2002.

HUANG, A.; WU, Y.; SUN, D.; KOLLER, A.; KALEY, G. Effect of estrogen on flow-induced dilation in NO deficiency: role of prostaglandins and EDHF. J. Appl. Physiol., v.9, p.2561-2566, 2001.

KANCHANA, G.; SUNDARAMOORTHI, P.; JEYANTHI, G.P. Bio-chemical analysis and FTIR-spectral studies of artificially removed renal stone mineral constituents. J. Miner. Mater. Character Eng., v.8, p.161-170, 2009.

KAPLAN, N.M.; OPIE, L.H. Controversies in Hypertension. Lancet, v.367, p.168-176, 2006.

KHAN, A.U.; MUSTAFA, M.R.; KHAN, A.U.; MURUGAN, D.D. Hypotensive effect of Gentiana floribunda is mediated through $\mathrm{Ca}^{++}$antagonism pathway. BMC Complement. Altern. Med., v.11, p.112-121, 2012.

LAHLOU, S.; GALINDO, C.A.; LEAL-CARDOSO, J.H.; FONTELES, M.C.; DUARTE, G.P. Cardiovascular effects of the essential oil of Alpinia zerumbet leaves and its main constituent, terpinen-4-ol, in rats: role of the autonomic nervous system. Planta Med., v.68, p.1097-1102, 2002.
LAHLOU, S.; INTERAMINENSE, L.F.; LEAL-CARDOSO, J.H.; DUARTE, G.P. Antihypertensive effects of the essential oil of Alpinia zerumbet and its main constituent, terpinen-4-ol, in DOCA-salt hypertensive conscious rats. Fundam. Clin. Pharmacol., v.17, p.323-330, 2003.

LAPA FDA, R.; SOARES, K.C.; RATTMANN, Y.D.; CRESTANI, S.; MISSAU, F.C.; PIZZOLATTI, M.G.; MARQUES, M.C.; RIECK, L.; SANTOS, A.R. Vasorelaxant and hypotensive effects of the extract and the isolated flavonoid rutin obtained from Polygala paniculata L. J. Pharm. Pharmacol., v.63, p.875-881, 2011.

LEITE, K.R.; ANDRADE, L.S.; SENA, J.S.; VILAR, J.B.; CHEN, L.C. Avaliação da atividade mutagênica e genotóxica de Ginkgo biloba L. pelo teste do micronúcleo em camundongos. Rev. Biol. Neotrop., v.3, p.157-162, 2006.

LUKSHA, L.; AGEWALL, S.; KUBLICKIENE, K. Endothelium-derived hyperpolarizing factor in vascular physiology and cardiovascular disease. Atherosclerosis, v.202, p.330-344, 2009.

MAITZ, M.F.; PHAM, M.T.; MATZ, W.; REUTHER, H.; STEINER, G. Promoted calcium-phosphate precipitation from solution on titanium for improved biocompatibility by ion implantation. Surf. Coat. Technol., v.158-159, p.151$156,2002$.

MAJEWSKA-WIERZBICKA, M.; CZECZOT, H. Flavonoids in the prevention and treatment of cardiovascular diseases. Pol. Merkur. Lekarski, v.32, p.50-54, 2012.

MÄKYNEN, H.; KÄHÖNEN, M.; ARVOLA, P.; WUORELA, H.; VAPAATALO, H.; PÖRSTI, I. Dietary calcium and magnesium supplements in spontaneously hypertensive rats and isolated arterial reactivity. Br. J. Pharmacol., v.115, p.1455-1462, 1995.

MARINOVA, D.; RIBAROVA, F.; ATANASSOVA, M. Total phenolics and total flavonoids in bulgarian fruits and vegetables. J. Univ. Chem. Technol. Metallurg., v.40, p.255$260,2005$.

MENDONÇA, V.L.M.; OLIVEIRA, C.L.A.; CRAVEIRO, A.A.; RAO, V.S.; FONTELES, M.C. Pharmacological and toxicological evaluation of Alpinia speciosa. Mem. Inst. Oswaldo Cruz, v.86, p.93-97, 1991. 
MLADENKA, P.; ZATLOUKALOVÁ, L.; FILIPSKÝ, T.; HRDINA, R. Cardiovascular effects of flavonoids are not caused only by direct antioxidant activity. Free Radic. Biol. Med., v.49, p.963-975, 2010.

MPALATINOS, M.A.; MOURA, R.S.; PARENTE, J.P.; KUSTER, R.M. Biologically active flavonoids and kava pyrones from the aqueous extract of Alpinia zerumbet. Phytother. Res., v.12, p.442-444, 1998.

NDIAYE, M.; CHATAIGNEAU, T.; ANDRIANTSITOHAINA, R.; STOCLET, J.C.; SCHINI-KERTH, V.B. Red wine polyphenols cause endothelium-dependent EDHF-mediated relaxations in porcine coronary arteries via a redox-sensitive mechanism. Biochem. Biophys. Res. Commun., v.310, p.371-377, 2003.

ORGANIZATION FOR ECONOMIC CO-OPERATION AND DEVELOPMENT (OECD). Guideline for the testing of chemicals mammalian erythocyte micronucleous test. OECD: 1997. p.1-10.

PURWANTININGSIH; HUSSIN, A.H.; CHAN, K.L. Free radical scavenging activity of the standardized ethanolic extract of Eurycoma longifolia (TAF-273). Int. J. Pharm. Pharm. Sci., v.3, p.343-347, 2011.

RAMASSAMY, C. Emerging role of polyphenolic compounds in the treatment of neurodegenerative diseases: a review of their intracellular targets. Eur. J. Pharmacol., v.545, p.51-64, 2006.

RIBEIRO, L.R. Teste do micronúcleo em medula óssea de roedores in vivo. In: RIBEIRO, L.R.; SALVADORI, D.M.F.; MARQUES, E.K. (Eds.). Mutagênese ambiental. Canoas: Ulbra, 2003. p.173-200.

ROCHA, A.P.; CARVALHO, L.C.; SOUSA, M.A.; MADEIRA, S.V.; SOUSA, P.J.; TANO, T.; SCHINI-KERTH, V.B.; RESENDE, A.C.; DE MOURA, R.S. Endotheliumdependent vasodilator effect of Euterpe oleracea Mart. (Açaí) extracts in mesenteric vascular bed of the rat. Vascul. Pharmacol., v.46, p.97-104, 2007.

SENEJOUX, F.; GIRARD, C.; AISA, H.A.; BAKRI, M.; KERRAM, P.; BERTHELOT, A.; BÉVALOT, F.; DEMOUGEOT, C. Vasorelaxant and hypotensive effects of a hydroalcoholic extract from the fruits of Nitraria sibirica Pall. (Nitrariaceae). J. Ethnopharmacol., v.141, p.629-634, 2012.
SHIMOKAWA, H.; YASUTAKE, H.; FUJI, K.; OWADA, M.K.; NAKAIKE, R.; FUKUMOTO, Y.; TAKAYANAGI, T.; NAGAO, T.; EGASHIRA, K.; FUJISHIMA, M.; TAKESHITA, A. The importance of the hyperpolarizing mechanism increases as the vessel size decreases in endothelium-dependent relaxations in rat mesenteric circulation. J. Cardiovasc. Pharmacol., v.28, p.703-711, 1996.

SINGLETON, V.L.; ROSSI, J.A.J.R. Colorimetry of total phenolics with phosphomolybdic-phosphotungstic acid reagents. Am. J. Enol. Viticult., v.16, p.144-158, 1965.

SONCINI, R.; SANTIAGO, M.B.; ORLANDI, L.; MORAES, G.O.; PELOSO, A.L.; DOS SANTOS, M.H.; ALVESDA-SILVA, G.; PAFFARO JR, V.A.; BENTO, A.C.; GIUSTI-PAIVA, A. Hypotensive effect of aqueous extract of Averrhoa carambola L. (Oxalidaceae) in rats: an in vivo and in vitro approach. J. Ethnopharmacol., v.133, p.353$357,2011$.

TADDEI, S.; VERSARI, D.; CIPRIANO, A.; GHIADONI, L.; GALETTA, F.; FRANZONI, F.; MAGAGNA, A.; VIRDIS, A.; SALVETTI, A. Identification of a cytochrome P450 2C9-derived endothelium- derived hyperpolarizing factor in essential hypertensive patients. J. Am. Coll. Cardiol., v. 48 , p.508-515, 2006.

THAYER, J.F.; LANE, R.D. The role of vagal function in the risk for cardiovascular disease and mortality. Biol. Psychol., v.74, p.224-242, 2007.

TÖRÖK, J. Histamine-induced relaxation in pulmonary artery of normotensive and hypertensive rats: relative contribution of prostanoids, nitric oxide and hyperpolarization. Physiol. Res., v.49, p.107-114, 2000.

UNITED STATES PHARMACOPEIA. USP. Water Determination USP29-NF24. Rockville: The United States Pharmacopeial Convention, 2006. p.2785.

VICTÓRIO, C.P.; KUSTER, R.M.; MOURA, R.S.; LAGE, C.L.S. Vasodilator activity of extracts of field Alpiniapurpurata (Vieill) K. Schum and A. zerumbet (Pers.) Burtt et Smith cultured in vitro. Braz. J. Pharm. Sci., v.45, p.507-515, 2009a.

VICTÓRIO, C.P.; KUSTER, R.M.; LAGE, C.L.S. Detection of flavonoids in Alpinia purpurata (Vieill) K. Schum.leaves by high-performance liquid chromatography. Rev. Bras. Plantas Med., v.11, p.147-153, 2009b. 
VICTÓRIO, C.P.; KUSTER, R.M.; LAGE, C.L.S. Production of rutin and kaempferol-3-O-glucuronide by tissue cultures of Alpinia purpurata (Vieill) K. Schum. Lat. Am. J. Pharm., v.28, p.613-616, 2009c.

YANGA, Q.; YIMA, P.; HE, G.W. The significance of endothelium-derived hyperpolarizing factor in the human circulation. Curr. Vasc. Pharmacol., v.5, p.85-92, 2007.
WORLD HEALTH ORGANIZATION. WHO. International Society of Hypertension Guidelines for the management of hypertension: guidelines subcommittee. J. Hypertens., v.17, p.151-183, 1999.

WORLD HEALTH ORGANIZATION. WHO. International Society of Hypertension Writing Group: WHO/ISH statement on management of hypertension. J. Hypertens., v.21, p.1983-1992, 2003.

Received for publication on $03^{\text {rd }}$ May 2013 Accepted for publication on $14^{\text {th }}$ November 2013 